\title{
COVID-19, elites and the future political economy of inequality reduction in Latin America
}

\author{
Benedicte Bull and Francisco Robles Rivera
}

\begin{abstract}
The literature is divided on the impact of pandemics on income inequality. The economic literature points to an increase in inequality as a result of pandemics, whereas historical and political science literature argue that pandemics may create breakdowns of institutions, maintaining inequality due to elite shifts and pressure from below. We review current data on the impact of COVID-19 and find that there is evidence of an upward income transfer as well as some elite shifts in the region. However, elites have controlled the economic measures to alleviate and confront the crisis and there is little evidence of a resultant institutional breakdown.
\end{abstract}

\section{Keywords}

COVID-19, viruses, epidemics, economic aspects, income distribution, elite, wealth, poverty, economic policy, Latin America

\section{JEL classification}

N46, P16, D36

\section{Authors}

Benedicte Bull is a professor in the Centre for Development and the Environment (SUM) at the University of Oslo, Norway. Email: benedicte.bull@sum.uio.no.

Francisco Robles Rivera is a researcher in the Institute of Social Research and Lecturer at the School of Communication at the University of Costa Rica. Email: francisco.robles@ucr.ac.cr. 


\section{Introduction}

The debate on the effect of the coronavirus disease (COVID-19) on inequality has changed dramatically over the last months. While COVID-19 was portrayed as "the great equalizer" in the early stages of the spread of the infection and lockdown measures (Mein, 2020), evidence now abounds that the pandemic will increase poverty and inequality (Busso and Messina, 2020). The Economic Commission for Latin America and the Caribbean (ECLAC) reports that the pandemic could cause a variation in the Gini inequality index of more than 3 percentage points in some countries, while the number of people living in poverty will increase by 4.4 percentage points (28.7 million more people) to $34.7 \%$ of the region's population (ECLAC, 2020a). This is a result of many factors, including the widespread loss of low-paying jobs and the fact that informal own-account workers have been prevented from conducting their regular economic activities. At the same time, recent evidence suggests that the income of the top earners has increased since March 2020 (Ruiz, 2020).

The literature on the impact of pandemics on inequality is inconclusive. Some studies show that pandemics disproportionally affect the poor and produce overall increases in income inequality (Cohn and Alfani, 2007; Karlsson, Nilsson and Pichler, 2014). Others show how pandemics and other crises have created disruptions, leading to a redistribution of assets as well as the institutional changes necessary for income redistribution (Piketty, 2017; Scheidel, 2018). This paper explores the argument that the long-term outcome depends on the extent to which crises change elites'1 resources and their influence on institutions and policies (Solimano, 2014). If a crisis essentially transfers income upwards without provoking an elite change, a deepening of inequality can be expected. If, on the other hand, a crisis forces elites to be more attentive to the demands of non-privileged groups, it is possible that a restructuring of institutions that perpetuate the culture of privilege will be required and that inequality will be reduced in the long term. However, it is also conceivable that elite groups that are incurring losses as a result of the pandemic could seek to maintain privileges through tighter control of institutions and resistance to redistributive measures.

In this paper, we review the limited data available on income concentration among the top earners since the start of the COVID-19 pandemic, as well as information on the distribution of resources among different elite groups and the reactions of the elite to the measures implemented to control the pandemic. On this basis, we seek to determine whether COVID-19 could result in a disruption, with the potential for improved distribution of resources, or whether it will merely result in an upward transfer of resources with the maintenance of the status quo.

The article is divided into seven sections, including this introduction. Section II reviews the literature on the relationship between pandemics and inequality and section III presents a brief overview of economic inequality in Latin America. Section IV analyses the upward transfer of income during the COVID-19 pandemic and section $V$ examines whether the crisis is creating a shift in elites. Section VI presents a discussion of elite influence on government measures to tackle the pandemic and section VII concludes.

\section{Pandemics, inequality and elites}

There is conclusive evidence that inequality is a major determinant of the extent and impact of pandemics throughout history. During the 1918 Spanish flu pandemic, mortality rates varied considerably by income between and within countries, particularly in cities and towns with a high degree of social

\footnotetext{
Elites are defined as groups of individuals whose control over natural, economic, political, coercive, social, organizational and/or symbolic (expertise or knowledge) resources give them a position of privilege to exert formal or informal influence on organizations and institutional practices (see Bull, 2014).
} 
inequality (Mamelund, 2017). During the 2009 influenza A (H1N1) virus pandemic, the mortality rate was 20 times higher in some South American countries than in Europe and three times higher in the most socioeconmically deprived quintiles of England's population than the most affluent quintile (Rutter and others, 2012; Simonsen and others, 2013). In his analysis, Turchin (2018) found a strong statistical association between levels of inequality and global connectedness and the impact of pandemics. There is also an increasing body of evidence suggesting that COVID-19 infection rates and death rates are likely to be higher among poor and marginalized groups (Galasso, 2020). While the leading cause of higher infection and death rates among the poor during earlier pandemics was the deterioration of health, sanitary and housing conditions, current digital and labour inequalities also result in disparities in the ability to comply with physical distancing.

However, the evidence is less conclusive with regard to how pandemics in turn affect patterns of inequality. The economic strand of the literature concludes that pandemics and large epidemics have increased inequality. Focusing on five major events since 2000, Furceri and others (2020) find that pandemics lead to a persistent increase in inequality, measured by the Gini coefficient. Their model shows that five years after a pandemic, the Gini of market income and the Gini of net income increase by $0.75 \%$ and $1.25 \%$, respectively. Pandemics also raised the income share of the upper deciles (Furceri and others, 2020). This is in line with other evidence that dramatic events such as wars or financial crises generally increase inequality (De Haan and Sturm, 2017). Among the reasons for this are that individuals with higher incomes are better able to adjust to changing labour markets and new business opportunities.

The historical and political science strands reach different conclusions. Pandemics have been among the great levellers of wealth and income through history, along with mass mobilization warfare, revolutions and State collapse (Scheidel, 2018). For example, the redistributive changes of the mid-twentieth century in Europe and the United States can be explained by a succession of global crises: the First World War, the Second World War and the Great Depression (Piketty, 2017; Starr, 2019). One of the reasons that pandemics have a positive effect on income distribution is that they hit the poor hardest, lead to labour scarcity and create the conditions for an increase in wages. During periods of stability and economic growth, elites focus on establishing laws and rules that allow for wealth concentration and the intergenerational transfer of wealth (Fukuyama, 2011; Scheidel, 2018). This is determined by their capacity to invest and generate employment (structural power) and their capacity to carry out political actions (instrumental power) (Fairfield, 2015). In Latin America, the "a culture of privilege" that developed over time is a system of values that perpetuates advantages to specific population groups based on their socioeconomic position, membership in political and cultural elites or ancestry (Bielschowsky and Torres, 2018). In contrast, in times of crisis, the focus is on short-term survival and overcoming threats. These are times when ideas of social equality gain acceptance, as elites are pressured to cooperate with and distribute income to lower classes, with a long-term impact on income distribution (Peacock and Wiseman, 1961; Starr, 2019). ${ }^{2}$ While reductions in income inequality may also result from periods of stability and growth - as seen in Latin America between 2003 and 2014- without a redistribution of assets and institutional change, such episodes may be short-lived (Rodríguez Weber, 2018).

However, the outcome of pandemics and other crises will not necessarily be homogenous. Collier and Collier (1991) show how the incorporation of labour into political institutions during the "critical junctures" of the 1930s shaped the paths to democracy and had very different outcomes in the years that followed. In the same way, the institutional handling of the COVID-19 crisis will affect both future inequality and democracy. The commonly held idea that inequality generally leads to the failure

\footnotetext{
2 This was the case with social conflicts of the 1930s in the Scandinavian countries, which saw the conclusion of agreements between workers and employers that led to a decline in income inequality over the following seven decades. See Bull (2019).
} 
of democracy finds limited support in research. ${ }^{3}$ However, high levels of income concentration affect the quality of democracy and, in particular, the degree to which democratic institutions are capable of enacting, implementing and sustaining distributive reforms, since powerful elites have more resources to oppose redistributive policies (Acemoglu and Robinson, 2019; Moene, 2015). This is partly because a higher concentration of wealth and resources weakens crucial democratic actors such as the media, social movements and unions (Durand, 2019).

The conclusions of both strands of literature with regard to the inequality effects of pandemics are not necessarily contradictory. The increase in inequality found in the economic literature, which focuses on a limited period of time, is based on the observations of the direct effects of pandemics and other crises. The conclusion from historical literature that the long-term outcome of a crisis is determined by changes in elites' sources of power and their support for institutions and redistributive measures means that an upward transfer of income without pressure for institutional disruption will deepen inequality. However, if the crisis generates redistribution of resources and creates pressure from below, elites are more likely to enter into new social contracts that could reduce inequality in the longterm. The persistence of the structural conditions that make Latin America the most unequal region in the world is often explained by elites' ability to maintain inequality-generating institutions even during democratic periods with large-scale social mobilization (Rovira-Kaltwasser, 2018).

\section{The starting point: wealth concentration and structural inertia in Latin America}

The reduction in poverty and inequality in Latin America between 2003 and 2014 can be attributed to a combination of favourable global economic conditions, increases in education levels (leading to a lower skill premium) and social and labour market policy (Busso and Messina, 2020). ${ }^{4}$

However, falling inequality in Latin America had little effect on the incomes of the top earners. The limited data available indicate that the top 1\% earn around $20 \%$ of total income, with few signs that this figure has declined (Alvaredo and others, 2018). New evidence in Morgan (2017) showed that in 2015 the richest 1\% accounted for as much as 28.3\% of the total income in Brazil and that the top $10 \%$ earned more than half (55.6\%) of total income. ${ }^{5}$ In the case of Chile, data for 2005-2010 show the top 1\% earning around 30.5\% of total income and the richest 0.01\% earning 10.1\% (López Vega, Figueroa and Gutiérrez, 2013). The World Bank (2018b) estimates that on average in the region, the top $10 \%$ hold one third of national income (see table 1 ).

In addition, there was no major redistribution of assets (Cornia, 2014). The Gini coefficient of wealth in Latin America is much higher than the average Gini of income, but comparable historical data are scarce (Amarante and Jiménez, 2015). Yet, there is little evidence of any major positive shift in asset inequality or any other major structural changes.

\footnotetext{
3 There is little to support the claims that democracy leads to the equal distribution of wealth and that wealth inequality leads to democratic failure. The widespread assertion that Latin America has always been more unequal, and thus less democratic, than other regions has also been disproved on several counts. See Scheve and Stasavage (2017).

4 The main exception to this trend was Costa Rica, where inequality increased (Trejos and Oviedo, 2012).

5 Income here corresponds to pre-tax national income.
} 
Table 1

Latin America (17 countries): national income held by the richest 10\% and Gini index, by country, 2008-2018

(Percentages, average values for the period)

\begin{tabular}{lcc}
\hline & Income held by the richest 10\% & Gini index \\
\hline Brazil & 41.95 & 53.14 \\
\hline Colombia & 41.45 & 52.30 \\
\hline Honduras & 39.97 & 52.57 \\
\hline Panama & 39.06 & 51.03 \\
\hline Paraguay & 38.55 & 49.07 \\
\hline Guatemala & 38.00 & 48.30 \\
\hline Mexico & 37.98 & 47.70 \\
\hline Costa Rica & 37.27 & 48.73 \\
\hline Chile & 37.06 & 45.52 \\
\hline Dominican Republic & 36.07 & 46.08 \\
\hline Nicaragua & 35.70 & 45.05 \\
\hline Ecuador & 35.50 & 46.52 \\
\hline Bolivia (Plurinational State of) & 34.30 & 46.46 \\
\hline Peru & 33.28 & 44.48 \\
\hline El Salvador & 32.55 & 42.04 \\
\hline Uruguay & 31.06 & 41.50 \\
\hline Argentina & 30.58 & 42.53 \\
\hline Source:Prepar & &
\end{tabular}

Source: Prepared by the authors, on the basis of World Bank, "Gini Index (World Bank estimate)", 2018 [online] https://data.worldbank.org/indicator/SI.POV.GINI, and "Income share held by highest 10\%", 2018 [online] https://data.worldbank.org/indicator/SI.DST.10TH.10.

Note: Data for Guatemala correspond to 2014. Data for Nicaragua are from 2009 and 2014.

In the absence of structural changes leading to a transformation in the distribution of assets and the elites controlling them, episodes of reduction of inequality may be short-lived. In Brazil, the pro-poor agenda and equality-driven growth adopted by Workers' Party (PT) governments in lieu of profound redistribution arguably made the process unsustainable in the long term (Loureiro, 2020). In Colombia, two main factors have played a role in inhibiting better income distribution: first, landed elites that have historically shaped local policies and decision-making to their benefit (Faguet, Sánchez and Villaveces, 2020); and second, powerful business groups that influence tax policies and whose focus has been on indirect taxation and avoiding high income tax rates (Castañeda, 2018). The case of Honduras is a particular one, as democratic institutions are extremely weak and elite networks have relied on their control of money, power and the media, which, in turn, have further undermined any redistributive policy attempts (Euraque, 2019; Sosa Iglesias, 2017). In Panama, the new institutional framework created in 1999 provided incentives for business elites to promote and develop an advantageous liberal regime in the country (Kasahara, 2012; Pérez, 2011). Nevertheless, since 2009, infighting among elites over the control of government and corruption scandals have shown that a small but powerful faction of the business elite could wield considerable direct control of State administration to serve private interests (Cárdenas and Robles Rivera, 2020; Santos and Fraga, 2020). The main question now is how the balance of power between elite interests is affected by the COVID-19 crisis. 


\section{Upward income transfers amid the COVID-19 pandemic}

Recent data suggest that the income and fortunes of the top earners and wealth holders have increased during the COVID-19 pandemic, contradicting early estimates. While we lack comparable data on the top $1 \%$ or the top $10 \%$ since the onset of the pandemic, we have used data on the income and wealth of the top earners based, inter alia, on the financial statements of major companies. ${ }^{6}$

Using these data, Gneiting, Luisani and Tamir (2020) find that, at a global level, excessive shareholder payouts prior to the onset of COVID-19 are a major reason for the financial trouble many large companies currently face. Between 2010 and 2019, the companies listed in the S\&P 500 index spent US\$ 9.1 trillion on payouts to their wealthy shareholders, equalling over $90 \%$ of their profits over that same period. Since January 2020, many large companies have increased their payment to shareholders. For example, since January, according to company reports, Microsoft and Google have paid shareholders over US\$21 billion and US\$15 billion, respectively. This is not exclusive to technology companies. The world's six largest oil companies ${ }^{7}$ had a combined net loss of US\$ 61.7 billion from January to July 2020 but managed to pay out US\$ 31 billion to shareholders during the same time period (Gneiting, Lusiani and Tamir, 2020).

In an analysis of wealth trends in Latin America, calculated by comparing the net worth of the region's billionaires on 18 March 2020 and on 12 July 2020, Oxfam (2020) finds that during this period, the combined net worth of billionaires in Argentina increased from US\$ 8.8 billion to US\$11.2 billion; in Brazil from US\$123.1 billion to US\$157.1 billion; in Colombia from US\$13.7 billion to \$14.1 billion; in Chile from US\$ 21 billion to US\$ 26.7 billion; in Peru from US\$ 5.2 billion to US\$ 5.5 billion; and in the Bolivarian Republic of Venezuela from US\$ 3.4 billion to US\$ 3.5 billion. $^{8}$

In total, the wealth of the 73 richest Latin Americans grew by US\$ 48.200 billion, or $17 \%$ since the beginning of the pandemic. Since the start of lockdown, the region has seen on average a new billionaire every two weeks (Ruiz, 2020). It is too early to say how the pandemic will affect the somewhat broader category referred to as high net-worth individuals (HNWI). ${ }^{9}$ The World Wealth Report 2020 shows that while the growth of global wealth stalled in 2018-2019, the number of HNWIs increased by 8.6\%. In the United States, the number of HNWIs shot up by a record $11 \%$. The number of Latin American HNWIs also increased in this low-growth period, although by only $2.7 \%$. The report notes that despite a dwindling global economy due to COVID-19, financial markets could prove resilient and boost the global outlook for HNWIs (Capgemini, 2020). Thus, although the recovery of Latin American stock markets has been slow and uneven since they plummeted in March-April 2020, the effect on the highest incomes may not be severe.

At the same time, according to International Labour Organization (ILO) figures for June 2020, unemployment had risen sharply due to COVID-19, leaving an unprecedented 41 million Latin Americans unemployed (ILO, 2020a). While unemployment during previous crises in Latin America has affected the middle classes, unemployment arising from COVID-19 has particularly harmed the poor owing to the nature of their work (Busso and Messina, 2020). Less than $10 \%$ of the poorest $40 \%$ of Latin Americans are able to work from home, either because they lack access to communication technologies or because their jobs require physical presence (Delaporte and Peña, 2020). Early research from Spain and the

6 Gneiting, Luisani and Tamir (2020) draw on the S\&P Capital IQ platform: an investor-grade financial analysis database, corroborated as necessary with a careful analysis of annual and quarterly financial reports of the companies.

7 The companies are Exxon Mobil, Total, Shell, Petrobras, Chevron and BP. See Coffey and others (2020).

8 See also Ruiz (2020).

9 These are defined as individuals having investable assets of US\$ 1 million or more, excluding primary residence, collectibles, consumables and consumer durables. 
United States that can be applied to Latin America shows two main trends (Aspachs and others, 2020; Béland, Brodeur and Wright, 2020). First, there was an increase in the unemployment rate and a decrease in working hours and labour force participation. Second, the negative impact was greater on younger workers, migrants and less educated workers. Both trends will heighten labour market inequalities (Béland, Brodeur and Wright, 2020). In Latin America and the Caribbean, ILO estimates that the loss of working hours in the third quarter of 2020, relative to the fourth quarter of 2019 is $25.6 \%$. This is accompanied by a steep drop in labour income for the first three quarters of 2020, with a loss of $19.3 \%$ as a percentage of labour income and $10.1 \%$ as a percentage of gross domestic product (GDP) (ILO, 2020b).

COVID-19 has also had a deleterious effect on small and medium-sized enterprises (SMEs) and particularly microenterprises. Early data from ECLAC suggested that $7.1 \%$ of small businesses and $20.7 \%$ of microenterprises would close before the end of 2020 (ECLAC, 2020b). Later data from OECD suggest that the number will be much higher. While 38\% of SMEs in Latin America were closed during the first half of 2020, 27\% of these remained closed by end-June (OECD/Facebook, 2020).

In previous crises, the establishment of SMEs has been a "survival strategy" (Mungaray Lagarda and others, 2015). SMEs in Latin America are also considered to be particularly capable of adapting to adverse conditions, i.e. during crises (Bernal and Michel, 2016). However, strict lockdown measures and plummeting demand for goods and services have prevented SMEs from overcoming their main challenge in times of crisis, which is their generally low liquidity (OECD/Facebook, 2020).

While it is still too early to draw firm conclusions, the above data suggest that wealth is being transferred upwards, from lower income segments to high income groups, and particularly to the very top income earners and wealth holders. This will probably deepen inequality. However, it is also possible that wealth will shift from one elite group to another.

\section{Elite shifts as a result of COVID-19?}

The upward transfer of wealth has not been even across sectors. The quarantining of millions of people across the region and closure of hundreds of shops have benefited digital platforms. In Argentina, two major companies -Mercado Libre and Globant- saw their stock prices increase. In the case of Mercado Libre, the stock price soared from US\$ 602 in August 2019 to US\$1,277 in August 2020 (see table 2) and its sales were up by 45\% compared with 2019 (Ventrici, Krepki and Palermo, 2020). Globant's stock price, for its part, almost doubled year-on-year. Some of Brazil's major online-based companies, such as PagSeguro Digital and StoneCo Ltd, also performed well, with share prices gaining in value since the beginning of the pandemic (Kitchener, 2020).

Table 2

Argentina and Brazil: variation in digital platforms' stock prices, 2019 and 2020 (Dollars)

\begin{tabular}{lccc}
\hline Company & Stock price on 26 August 2019 & Stock price on 23 March 2020 & Stock price on 27 August 2020 \\
\hline StoneCo Ltd (BRA) & 30.51 & 19.89 & 50.56 \\
\hline PagSeguro Digital Ltd (BRA) & 50.30 & 14.95 & 44.19 \\
\hline Mercado Libre (ARG) & 602.62 & 457.65 & 1201.40 \\
\hline Globant (ARG) & $92.89^{a}$ & 73.50 & 177.00 \\
\hline
\end{tabular}

Source: Prepared by the authors, on the basis of National Association of Securities Dealers Automated Quotations (NASDAQ), "Stocks" [online] https://www.nasdaq.com/market-activity/stocks, and New York Stock Exchange (NYSE), "Listings Directory" [online] https://www.nyse.com/listings_directory/stock.

a This value corresponds to 28 August 2019. 
The pandemic has also increased governments' dependence on -and thus the potential influence of - specific companies. From the outset, the Argentine Government worked hand in hand with Big Tech companies such as Amazon, Microsoft and Google, as well as Globant and Mercado Libre in order to use their data to try to control the nationwide spread of the virus (Ventrici, Krepki and Palermo, 2020). Two of these initiatives include a digital dashboard to track available beds and respirators in the country's hospitals and a mobile health application called Cuidar that allows users to carry out self-diagnosis, trace contacts and access movement permits. The dashboard was developed in record time by Globant and the North American company, Salesforce, while the application was developed through a multi-partner project led by the Secretariat of Public Innovation. However, the government is completely dependent on the partner companies for the continued operation of the application (Ventrici, Krepki and Palermo, 2020). Indeed, the increasing wealth of the tech companies, combined with government dependence on these platforms, will reduce the chances of implementing a digital tax as proposed by civil society and international organizations (ECLAC, 2019).

The digital economy is booming in the region on the back of the pandemic, with news reports projecting that it will represent 40\% of the regional GDP by 2022 (Mari, 2019). However, by their very nature, these digital economies economies tend to concentrate resources in few companies. Early data show that economic winners of the pandemic are biotechnology, pharmaceutical, medical and Internet retail companies (Sokol and Pataccini, 2020).

On the other hand, economic shutdowns reduced exports, remittances and tourism - three key sources of income and wealth in the region. First, according to data from the first quarter of 2020, export values in Latin America fell by $3.2 \%$ as the economic contraction led to sharp declines in the prices of oil (-32.0\%) and copper (-11.9\%), with soybean and coffee prices also down by $2.2 \%$ and $4.4 \%$ respectively (Giordano, 2020). Second, there has been a decline in remittances. Preliminary data show that remittances were 17\% lower in April 2020 than in the year-earlier period in countries that rely heavily on remittances, such as Colombia, the Dominican Republic, El Salvador, Guatemala, Honduras and Mexico (Noe-Bustamante, 2020). The impact on the relationship between elites could be severe in Honduras and El Salvador, for example, where remittances accounted for approximately $20 \%$ of GDP in 2019, and business groups have adapted their strategies to capture them (Bull, Castellacci and Kasahara, 2014; Rocha, 2008). Third, the collapse in tourism may cause total GDP growth in the Caribbean and Latin America to fall by 8 percentage points and 1 percentage point, respectively (ECLAC, 2020c). This will weaken elites in the service sector.

An elite shift of a completely different nature could result from the strengthening of military elites thanks to their role in maintaining control over the population during lockdown measures. Such a shift has occurred in countries like Nicaragua and El Salvador, as well as in Colombia, the Plurinational State of Bolivia, Chile and the Bolivarian Republic of Venezuela. In some cases, this may translate into increased military control over the economy. For example, there has been an increase in extortion in the Bolivarian Republic of Venezuela amid the COVID-19 pandemic (De Jesús, 2020). Acts of extortion, whether committed by gangs or groups with military connections, are known to have led to the takeover of small businesses by armed groups (Bull, 2020). Further strengthening of the economic role of military elites is therefore possible.

In sum, the pandemic may cause a shift in the control of resources. Elite groups in technology, the pharmaceutical and health care industries and the digital economy will gain, while those who own shopping centers or benefit from exports, remittances and tourism - who traditionally were at the top - may now need government support to keep their businesses in operation. 


\section{Elite and government reactions to redistribution during the COVID-19 pandemic}

As mentioned above, the historical literature suggests that the nature of the pandemic, the type of institutions and income distribution determine whether elites accept or reject increased distribution of resources and the establishment of new institutions. It is too early to ascertain the willingness of elite groups to transform institutions amid the current pandemic. ECLAC data on the economic measures implemented by governments in response to COVID-19 as of September 2020 show that one third of these measures have been business-oriented policies (see figure 1). The emphasis on such policies is particularly strong in countries with pro-business governments, such as Brazil, Chile and Colombia.

Figure 1

Latin America (18 countries): economic measures implemented to address the COVID-19 pandemic, by type of measure and country, March-September 2020

(Numbers)

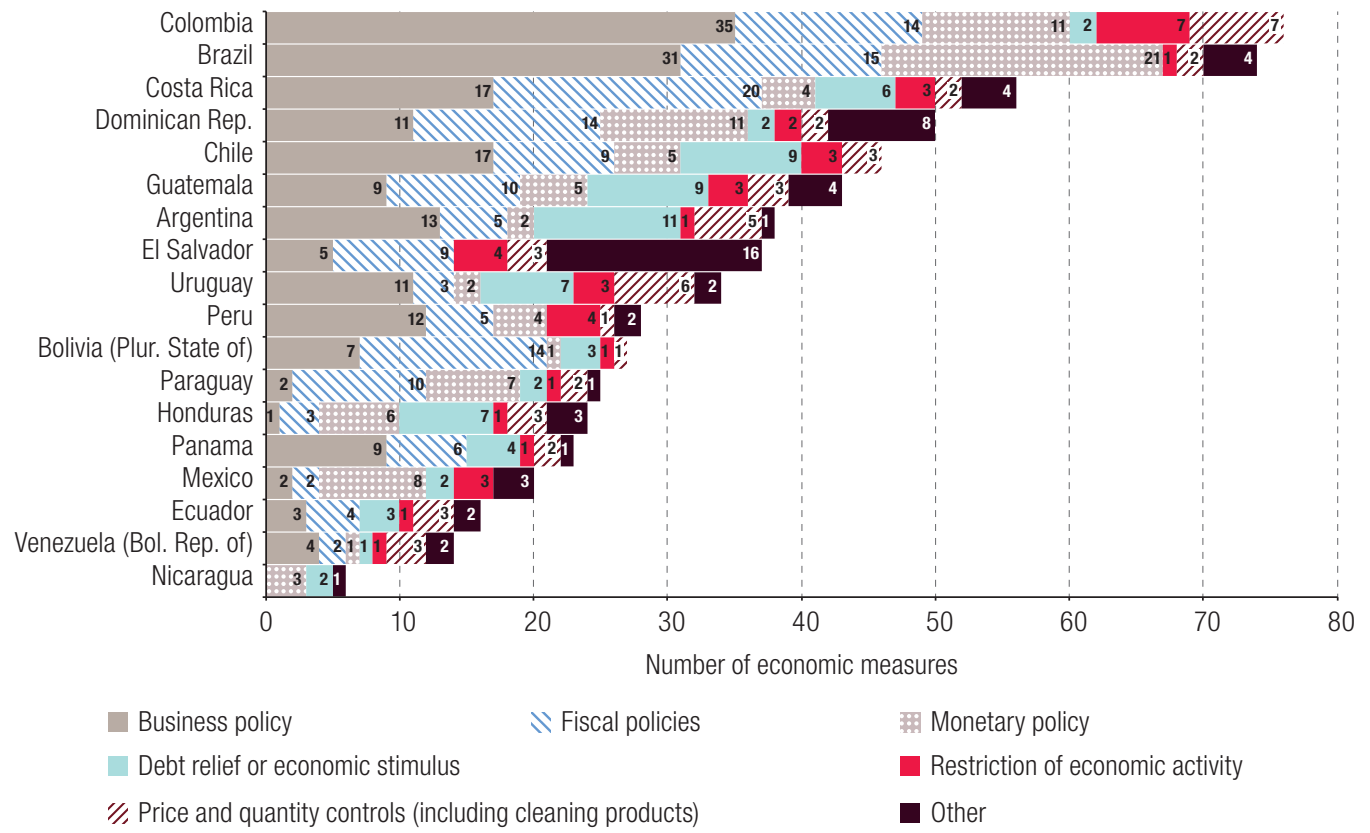

Source: Prepared by the authors, on the basis of Economic Commission for Latin America and the Caribbean (ECLAC), "Follow up of the evolution of COVID-19 Measures", 2020 [online] https://cepalstat-prod.cepal.org/forms/covid-countrysheet/index.html.

However, it is likely that the content of these policies or the extent to which they result from elite pressure, vary. In the following paragraphs, drawing on Bull and Aguilar-Støen (2019), Cárdenas, Robles Rivera and Martínez-Vallejo (2020), Robles Rivera (2014), Sánchez-Ancochea and Puig (2013) and Segovia (2005), we explore elite reactions during COVID-19, focusing on Central America, a region in which the elites have had recognized influence (see table 3). An early comparison of elite group's responses to policies to address the pandemic suggests a high correlation between the responses and their access to government as well as ethnicity (Pérez-Sáinz, 2016; Sánchez-Ancochea and Martínez-Franzoni, 2020). In Guatemala and Honduras, elite networks and family-owned diversified business groups have played a crucial role shaping the political agenda (Bull, Castellacci and Kasahara, 2014). In these countries, elites have historically been severely opposed to tax reforms and any State expansion, despite recent recognition of the importance of State institutions (Bull and Aguilar-Støen, 2019). As a result, tax levels are still the lowest in Latin America (OECD and others, 2020). During the COVID-19 
crisis, rather than promote institutional changes, governments have relied on corporate philanthropy to cope with the lack of medical supplies and food provision shortages (Cárdenas, Robles Rivera and Martínez-Vallejo, 2020). Examples include the opening in July of an early care and stabilization centre for COVID-19 patients by the Honduran Council of Private Enterprise (COHEP), in association with the Municipality of the Central District and the inauguration in September of the Hospital de Santa Lucía Cotzumalguapa in Guatemala, with donations in kind (construction site and medical equipment) from the Guatemalan Sugar Association (ASAZGUA) (Mutz, 2020). Similarly, in Mexico, business magnate Carlos Slim offered to fund the production of the vaccine under development by the University of Oxford and AstraZeneca for the Mexican market (El Heraldo de México, 2020). Instead of strengthening State capacities, these urgent and necessary actions have increased elites' bargaining power.

Table 3

Central America (5 countries): proposals and actions adopted by elites in response to the COVID-19 pandemic

\begin{tabular}{lll}
\hline Country & Type of relationship with government & Key proposals and actions \\
\hline El Salvador & Detachment & Corporate philanthropy \\
& & Tax reductions \\
& Opposition to lockdown \\
\hline Honduras & Capture & Corporate philanthropy \\
& & Tax reductions \\
& Foreign funding \\
\hline Costa Rica & Collaboration & Tax reductions \\
& & Restructuring of public employment \\
& Reduction of social security contributions \\
\hline Guatemala & Capture & Corporate philanthropy \\
& & Tax reductions \\
& & Foreign funding \\
\hline Nicaragua & Value added tax exemptions \\
& Detachment & Foreign funding \\
& Humanitarian fund \\
\hline
\end{tabular}

Source: Prepared by the authors, on the basis of Cárdenas, Robles Rivera and Martínez-Vallejo, "Élites empresariales y desigualdad en tiempos de pandemia en América Latina”, Revista Española de Sociología, vol. 29, No. 3, 2020.

In the neighbouring countries of El Salvador and Nicaragua, the pandemic may rather accelerate ongoing elite shifts whose outcomes remain highly uncertain. The co-government pact between the traditional Nicaraguan elite and the family of President Ortega (Spalding, 2017) was broken in 2018 when protests against a pension reform were met by mass repression and human rights violations. Nicaraguan elites have sought new channels of communication with the Ortega family, including during the pandemic, but without success. A similar scenario has shaped elite reactions to the pandemic in El Salvador. While, historically, Salvadoran elites played a crucial political role (Robles Rivera, 2017; Segovia, 2005), since the beginning of the crisis, President Nayib Bukele has publicly confronted the elites, leading to a public outcry of business associations against the lockdown measures implemented by the government (Cárdenas, Robles Rivera and Martínez-Vallejo, 2020).

In Costa Rica, elites' reactions have been shaped by their access to and collaboration with the government and a centre-right congress. ${ }^{10}$ The Alvarado administration appointed prominent businesspeople to oversee the economic sector (Cárdenas, Robles Rivera and Martínez-Vallejo, 2020). From the very onset of the COVID-19 crisis, elites have actively promoted policies and change through the national business association, the Costa Rican Union of Chambers and Associations of Private Enterprise, and an influential philanthropic organization, Horizonte Positivo. They have sought agreements to ease business regulation procedures (tramitología) (Murillo, 2020), advocating austerity

${ }^{10}$ According to data from the Parliamentary Elites of Latin America Project (PELA, 2018), on average the political parties elected
to congress in the period 2018-2022 can be described as "centre-right" based on their ideological self-placement and position. 
measures and smaller government, while rejecting new taxes (UCCAEP, 2020). This suggests that in countries where elites are highly cohesive and have control over resources, they seek to supervise public authorities rather than challenge them.

\section{VII.Conclusions}

It is now relatively clear that COVID-19 will be far from the "great equalizer" it was thought to be initially. The pandemic will increase poverty and will strike the lower-income strata more harshly than the middle classes owing to the different nature of their work. The big question now is how COVID-19 will affect wealth and income inequality in the future.

Latin America is characterized by high inequality of income as well as wealth. The period between 2003 and 2014 saw an improvement in income distribution, but no improvement in the distribution of wealth. The mechanisms that led to improvements in income distribution also proved unsustainable, partly for economic, but mainly for political reasons. The means introduced failed to produce positive feedback effects and long-term reforms and, in some cases, created strong opposition among elites (Chiasson-LeBel and Larrabure, 2019).

The historical literature suggests that pandemics can create the conditions for improved distribution if they serve as a "critical juncture" forcing elites to think about inclusion and distribution of resources. In this paper, we discussed the concentration of resources and elites' reactions to different redistributive measures in response to the COVID-19 pandemic. Preliminary data suggest that there has indeed been a transfer of resources upwards during the pandemic. However, the various elite groups have not all benefited in the same way. The trend shows that COVID-19 has concentrated income in the hands of the super rich (billionaires) and particularly, but not exclusively, those in the technology sectors.

There is little evidence that the pandemic has made very wealthy individuals more inclined to support distributive reforms. Rather, their observed involvement in various forms of corporate philanthropy may, in the end, strengthen the status quo. The increase in robotization and other phenomena also reduce the likelihood that demands for higher salaries will resonate due to labour shortages, which historically come on the heels of pandemics.

The COVID-19 pandemic is far from over. It could still generate such an extreme rupture that it provokes more profound change in some countries, particularly where major upheavals were already under way, such as in Chile. Where such a major disruption occurs also depends on changes in the global context. It now seems clear that we will see a global concentration of resources in the hands of two sets of actors: major multinational companies (most of which are owned in the United States), and Chinese companies. How they form linkages with local elites in Latin America will be a significant factor deciding the future of elites, institutions and redistribution.

\section{Bibliography}

Acemoglu, D. and J. Robinson (2019), The Narrow Corridor: States, Societies, and the Fate of Liberty, New York, Penguin Press.

Alvaredo, F. and others (eds.) (2018), World Inequality Report 2018, Cambridge, The Belknap Press of Harvard University Press.

Amarante, V. and J. Jiménez (2015), "Desigualdad, concentración y rentas altas en América Latina", Desigualdad, concentración del ingreso y tributación sobre las altas rentas en América Latina, J. Jiménez (ed.), ECLAC Books, No. 134 (LC/G.2638-P), Santiago, Economic Commission for Latin America and the Caribbean (ECLAC). 
Aspachs, O. and others (2020), "Real-time inequality and the welfare State in motion: evidence from COVID-19 in Spain", CEPR Discussion Papers, No. DP15118, London, Center for Economic and Policy Research (CEPR).

Béland, L. P., A. Brodeur and T. Wright (2020), "The short-term economic consequences of COVID-19: exposure to disease, remote work and government response", IZA Discussion Papers, No. 13159, Bonn, Institute of Labor Economics (IZA).

Bernal, T. and F. Michel (2016), "Diseño de un Assessment Center, buscando productividad de los recursos humanos en los procesos productivos de las pequeñas y medianas empresas", master's thesis, Guayaquil, University of Guayaquil [online] http://repositorio.ug.edu.ec/handle/redug/41551.

Bielschowsky, R. and M. Torres (comps.) (2018), Desarrollo e igualdad: el pensamiento de la CEPAL en su séptimo decenio. Textos seleccionados del período 2008-2018, Colección 70 años, No. 1 (LC/PUB.2018/7-P), Santiago, Economic Commission for Latin America and the Caribbean (ECLAC).

Bull, B. (2020), "Venezuela y el capitalismo del Siglo XXI: cambios visibles", La Lettre de l'IHEAL-CREDA, No. 40, April.

(2019), "Combating inequality: is there a 'Scandinavian way' to reduce inequality in Latin America?", Iberoamericana - Nordic Journal of Latin American and Caribbean Studies, vol. 48, No. 1. (2014), "Towards a political economy of weak institutions and strong elites in Central America", ERLACS - European Review of Latin American and Caribbean Studies, No. 97.

Bull, B. and M. Aguilar-Støen (2019), "Peace-building and business elites in Guatemala and El Salvador: explaining the discursive 'institutional turn'”, Conflict, Security \& Development, vol. 19, No. 1.

Bull, B., F. Castellacci and Y. Kasahara (2014), Business Groups and Transnational Capitalism in Central America: Economic and Political Strategies, Basingstoke, Palgrave Macmillan.

Busso, M. and J. Messina (eds.) (2020), The Inequality Crisis: Latin America and the Caribbean at the Crossroads, Inter-American Development Bank (IDB) [online] https://doi.org/10.18235/0002629.

Capgemini (2020), "World Wealth Report 2020" [online] https://worldwealthreport.com/.

Cárdenas, J. and F. Robles Rivera, F. (2020), Business Elites' Sources of Power and State Capture in Panama, Geneva, United Nations Research Institute for Social Development (UNRISD), forthcoming.

Cárdenas, J., F. Robles Rivera and D. Martínez-Vallejo (2020), "Élites empresariales y desigualdad en tiempos de pandemia en América Latina", Revista Española de Sociología, vol. 29, No. 3.

Castañeda, N. (2018), "Business groups, tax efficiency, and regressivity in Colombia", Rethinking Taxation in Latin America, J. Atria, C. Groll and M. Valdés (eds.), Cham, Springer International Publishing.

Chiasson-LeBel, T. and M. Larrabure (2019), "Latin America's changing balance of class forces: an introduction", ERLACS - European Review of Latin American and Caribbean Studies, No. 108.

Coffey, C. and others (2020), "Time to care: unpaid and underpaid care work and the global inequality crisis", Oxfam Briefing Paper, Oxford, Oxfam GB, 20 January [online] https://www.oxfam.org/en/research/time-care.

Cohn, S. and G. Alfani (2007), "Households and plague in early modern Italy", The Journal of Interdisciplinary History, vol. 38, No. 2.

Collier, R. and D. Collier (1991), Shaping the Political Arena: Critical Junctures, the Labor Movement, and Regime Dynamics in Latin America, Princeton, Princeton University Press.

Cornia, G. (2014), Falling Inequality in Latin America: Policy Changes and Lessons, Oxford, Oxford University Press.

De Haan, J. and J. E. Sturm (2017), "Finance and income inequality: a review and new evidence", European Journal of Political Economy, vol. 50, December.

De Jesús, L. (2020), "Microestados liderados por bandas criminales: crece la extorsión en Venezuela en medio de la pandemia", El Nacional, 31 August [online] https://www.elnacional.com/venezuela/microestadosliderados-por-bandas-criminales-crece-la-extorsion-en-venezuela/.

Delaporte, I. and W. Peña (2020), "Working from home under covid-19: who is affected? Evidence from Latin American and Caribbean countries", COVID Economics, Vetted and Real-Time Papers, No. 14, London, Center for Economic and Policy Research (CEPR), 6 May.

Durand, F. (2019), La captura del Estado en América Latina: reflexiones teóricas, Lima, Catholic University of Peru, Fondo Editorial.

ECLAC (Economic Commission for Latin America and the Caribbean) (2020a), "The social challenge in times of COVID-19", COVID-19 Special Report, No. 3, Santiago, 12 May. (2020b), "Mipymes y el COVID-19" [online] https://www.cepal.org/en/node/51732.

(2020c), "Recovery measures for the tourism sector in Latin America and the Caribbean present an opportunity to promote sustainability and resilience", COVID-19 Reports, July. 
(2019), Fiscal Panorama of Latin America and the Caribbean, 2019 (LC/PUB.2019/8-P), Santiago.

El Heraldo de México (2020), "Así informó Carlos Slim a AMLO sobre proyecto para crear vacuna contra Covid-19", 13 August [online] https://heraldodemexico.com.mx/pais/asi-informo-carlos-slim-a-amlosobre-proyecto-para-crear-vacuna-contra-covid-19/.

Euraque, D. (2019), "La configuración histórica de las élites de Honduras ante el golpe de Estado del 2009", Anuario de Estudios Centroamericanos, vol. 45, San José, University of Costa Rica.

Faguet, J. P., F. Sánchez and M. J. Villaveces (2020), "The perversion of public land distribution by landed elites: power, inequality and development in Colombia", World Development, vol. 136.

Fairfield, T. (2015), Private Wealth and Public Revenue in Latin America: Business Power and Tax Politics, New York, Cambridge University Press.

Fukuyama, F. (2011), The Origins of Political Order: from Prehuman Times to the French Revolution, New York, Farrar, Straus and Giroux.

Furceri, D. and others (2020), "Will Covid-19 affect inequality? Evidence from past pandemics", Covid Economics, Vetted and Real-Time Papers, No. 12, London, Center for Economic and Policy Research (CEPR), 1 May.

Galasso, V. (2020), "Covid: not a great equaliser", Covid Economics, Vetted and Real-Time Papers, No. 19, London, Center for Economic and Policy Research (CEPR), 18 May.

Giordano, P. (coord.) (2020), "Trade trends estimates: Latin America and the Caribbean, 2020 edition, Q1 update", Inter-American Development Bank (IDB) [online] https://doi.org/10.18235/0002390.

Gneiting, U., N. Lusiani and I. Tamir (2020), "Power, profits and the pandemic: from corporate extraction for the few to an economy that works for all", Oxfam Briefing Paper, Oxford, Oxfam GB, 10 September [online] https://oxfamilibrary.openrepository.com/handle/10546/621044.

ILO (International Labour Organization) (2020a), "ILO: sharp rise in unemployment in Latin America and the Caribbean leaves millions without income", 1 July [online] http://www.llo.org/caribbean/newsroom/ WCMS_749692/lang--en/index.htm.

(2020b), ILO Monitor: COVID-19 and the world of work, sixth edition, 23 September [online] ilo.org/ wcmsp5/groups/public/---dgreports/---dcomm/documents/briefingnote/wcms_755910.pdf.

Karlsson, M., T. Nilsson and S. Pichler (2014), "The impact of the 1918 Spanish flu epidemic on economic performance in Sweden: an investigation into the consequences of an extraordinary mortality shock", Journal of Health Economics, vol. 36, July.

Kasahara, Y. (2012), "Should I stay or should I go? A comparative study of banking sector policies and the strategies of Central American business groups", Business and Politics, vol. 14, No. 4.

Kitchener, S. (2020), "Latin American Equity Markets Staged Recovery in Q2 2020 despite Continuing Battle with COVID-19", S\&P Global, 21 July [online] https://www.spglobal.com/en/research-insights/articles/ latin-american-equity-markets-staged-recovery-in-q2-2020-despite-continuing-battle-with-covid-19.

López Vega, R., E. Figueroa and C. Gutiérrez (2013), “La 'parte del león': nuevas estimaciones de la participación de los súper ricos en el ingreso de Chile", Documentos de Trabajo, No. 379, Santiago, University of Chile.

Loureiro, P. (2020), "Class inequality and capital accumulation in Brazil, 1992-2013", Cambridge Journal of Economics, vol. 44, No. 1, January.

Mamelund, S. (2017), "Profiling a pandemic: who were the victims of the Spanish flu?", Natural History, special issue, September [online] https://oda-hioa.archive.knowledgearc.net/handle/10642/5480.

Mari, A. (2019), "Digital economy will represent over half of Latin America's GDP by 2022", ZDNet, 22 March [online] https://www.zdnet.com/article/digital-economy-will-represent-over-half-of-latin-americas-gdpby-2022/.

Mein, S. A. (2020), "COVID-19 and health disparities: the reality of 'the great equalizer'", Journal of General Internal Medicine, vol. 35, No. 8, August.

Moene, K. (2015), "The social upper class under social democracy", Nordic Economic Policy Review, No. 2, Copenhagen, Nordic Council of Ministers.

Morgan, M. (2017), "Extreme and persistent inequality: new evidence for Brazil combining national accounts, surveys and fiscal data, 2001-2015", WID. World Working Paper series, No. 12 [online] https:// fernandonogueiracosta.files.wordpress.com/2017/09/extreme-and-persistent-inequality-new-evidencefor-brazil-marc-morgan-wid-wp-2017-12.pdf.

Mungaray Lagarda, A. and others (2015), "Emprendimientos de micro y pequeñas empresas mexicanas en un escenario local de crisis económica: el caso de Baja California, 2008-2011”, Frontera Norte, vol. 27, No. 53. 
Murillo, A. (2020), "Asociación que presidió el ministro Garnier intervendrá en reducir trámites de Gobierno", Semanario Universidad, 28 May [online] https://semanariouniversidad.com/pais/asociacion-que-presidioel-ministro-garnier-intervendra-en-reducir-tramites-de-gobierno/.

Mutz, V. (2020), "Inauguran hospital permanente en Santa Lucía Cotzumalguapa”, República, 2 September [online] https://republica.gt/2020/09/02/inauguran-hospital-permanente-en-santa-lucia-cotzumalguapa/.

Noe-Bustamante, L. (2020), "Amid COVID-19, remittances to some Latin American nations fell sharply in April, then rebounded”, Pew Research Center, 31 August [online] https://www.pewresearch.org/fact-tank/2020/08/31/ amid-covid-19-remittances-to-some-latin-american-nations-fell-sharply-in-april-then-rebounded/.

OECD (Organization for Economic Cooperation and Development)/Facebook (2020), "Global State of Small Business Report: Wave II Update" [online] https://dataforgood.fb.com/wp-content/uploads/2020/08/ State-of-Small-Business-Report-Wave-II-Summary.pdf.

OECD (Organization for Economic Cooperation and Development) and others (2020), Revenue Statistics in Latin America and the Caribbean 2020, Paris.

Oxfam (2020), "Latin American billionaires surge as world's most unequal region buckles under coronavirus strain", 27 July [online] https://www.oxfam.org/en/press-releases/latin-american-billionaires-surge-worldsmost-unequal-region-buckles.

Peacock, A. and J. Wiseman (1961), The Growth of Public Expenditure in the United Kingdom, Princeton, Princeton University Press [online] https://www.nber.org/books/peac61-1.

PELA (Parliamentary Elites of Latin America) (2018), "Country databases" [online] https://oir.org.es/pela/en/ country-databases/.

Pérez, O. (2011), Political Culture in Panama: Democracy after Invasion, New York, Palgrave Macmillan.

Pérez-Sáinz, J. (2016), Una historia de la desigualdad en América Latina: la barbarie de los mercados, desde el siglo XIX hasta hoy, Buenos Aires, Siglo XXI Editores.

Piketty, T. (2017), Capital in the Twenty-First Century, Cambridge, The Belknap Press of Harvard University Press.

Robles Rivera, F. (2017), "Élites en El Salvador: cambios y continuidades (2000-2016)", Anuario de Estudios Centroamericanos, vol. 43, San José, University of Costa Rica.

(2014), "Transformaciones y concentración en grupos de poder económico en Costa Rica (1980-2012)", Revista Mexicana de Sociología, vol. 76, No. 1.

Rocha, J. (2008), "12 mil millones en remesas: ¿quién se come ese mandado?", Revista Envío, №. 313, Managua, University of Central America, April.

Rodríguez Weber, J. (2018), "Alta desigualdad en América Latina: desde cuándo y por qué", Munich Personal RePEc Archive, No. 87619, June.

Rovira-Kaltwasser, C. (2018), "Political elites in Latin America", The Palgrave Handbook of Political Elites, H. Best and J. Highley (eds.), London, Macmillan Publishers.

Ruiz, S. (2020), “¿Quién paga la cuenta? Gravar la riqueza para enfrentar la crisis de la COVID-19 en América Latina y el Caribe”, Oxfam Briefing Paper, 27 July [online] https://oxfamilibrary.openrepository.com/ handle/10546/621033.

Rutter, P. and others (2012), "Socio-economic disparities in mortality due to pandemic influenza in England", International Journal of Public Health, vol. 57, No. 4.

Sánchez-Ancochea, D. and J. Martínez-Franzoni (2020), Pactos sociales al servicio del bienestar en América Latina: ¿qué son y cuál es su papel en tiempos de crisis?, forthcoming.

Sánchez-Ancochea, D. and S. Puig (eds.) (2013), Handbook of Central American Governance, Abingdon, Routledge.

Santos, H. and G. Fraga (2020), "Corruption, production structure and economic development in developing countries", CEPAL Review, No. 130 (LC/PUB.2020/4-P), Santiago, Economic Commission for Latin America and the Caribbean (ECLAC).

Scheidel, W. (2018), The Great Leveler: Violence and the History of Inequality from the Stone Age to the Twenty-First Century, Princeton, Princeton University Press.

Scheve, K. and D. Stasavage (2017), "Wealth inequality and democracy", Annual Review of Political Science, vol. 20, May.

Segovia, A. (2005), Integración real y grupos de poder económico en América Central: implicaciones para el desarrollo y la democracia de la región, San José, Friedrich Ebert Foundation (FEF).

Simonsen, L. and others (2013), "Global mortality estimates for the 2009 influenza pandemic from the GLaMOR project: a modeling study", PLOS Medicine, vol. 10, No. 11.

Sokol, M., and L. Pataccini (2020), "Winners and losers in coronavirus times: financialisation, financial chains and emerging economic geographies of the COVID-19 pandemic", Journal of Economic and Social Geography, vol. 111, No. 3. 
Solimano, A. (2014), Economic Elites, Crises, and Democracy: Alternatives beyond Neoliberal Capitalism, New York, Oxford University Press.

Sosa Iglesias, E. (2017), "Transformaciones en las élites económicas, estado y el proceso de democratización y desdemocratización: el caso de Honduras, 1990-2017", Anuario de Estudios Centroamericanos, vol. 43, San José, University of Costa Rica.

Spalding, R. (2017), "Los empresarios y el estado posrevolucionario: el reordenamiento de las élites y la nueva estrategia de colaboración en Nicaragua", Anuario de Estudios Centroamericanos, vol. 43, San José, University of Costa Rica.

Starr, P. (2019), Entrenchment: Wealth, Power, and the Constitution of Democratic Societies, New Haven, Yale University Press.

Trejos, J. and L. Oviedo (2012), "Cambios en la distribución del ingreso familiar en Costa Rica durante la primera década del siglo XXI”, Revista de Ciencias Económicas, vol. 30, No. 2, San José, University of Costa Rica.

Turchin, P. (2018), Historical Dynamics: Why States Rise and Fall, Princeton, Princeton University Press.

UCCAEP (Costa Rican Union of Chambers and Associations of Private Enterprise) (2020), "Un pacto por el empleo: Día Nacional de la Empresa Privada”, San José, 25 February [online] https://www.uccaep.or.cr/ images/comunicados/Pacto-por-el-empleo-UCCAEP.pdf.

Ventrici, P., D. Krepki and H. Palermo (2020), "Sector software y la situación respecto de la pandemia de COVID-19”, El trabajo en los tiempos del COVID-19, No. 2, Buenos Aires, Centre of Labour Study and Research, 8 June.

World Bank (2018a), "Gini Index (World Bank estimate)" [online] https://data.worldbank.org/indicator/SI.POV. GINI [accessed on: 21 January 2020].

_(2018b), "Income share held by highest 10\%" [online] https://data.worldbank.org/indicator/SI.DST.10TH.10 [accessed on: 21 January 2020]. 